\title{
PENGAMBILKIRAAN REALITI SEMASA DALAM BERFATWA: ANALISIS TERHADAP FATWA ZAKAT DI SELANGOR
}

\author{
Addressing the Current Reality in Fatwa: \\ An Analysis of the Fatwa on Zakat in Selangor
}

\author{
Ummi Farahin Yasin* \\ Noor Naemah Abdul Rahman ** \\ Mohd Faez Mohd Shah ***
}

\begin{abstract}
This article attempts to analyse and discuss the fatwa on zakat by the Selangor Mufti Department from the year 2001 to 2011. Methods used in the analysis are library research, observation and interviews. Based on the analysis, it is found that when a fatwa on zakat is issued, the current developments of the society are considered by the fatwa committee. The Fatwa on zakat is not bound to the views from any mazhabs or particular Muslim scholars.
\end{abstract}

Keywords: Fatwa, Zakat, Selangor Mufti Department, Current Reality

\footnotetext{
* Pelajar Sarjana, Jabatan Fiqh dan Usul, Akademi Pengajian Islam, Universiti Malaya, farahin09@gmail.com

** Prof. Madya, Jabatan Fiqh dan Usul, Akademi Pengajian Islam, Universiti Malaya, naemah@um.edu.my

*** Pelajar Sarjana, Jabatan Fiqh dan Usul, Akademi Pengajian Islam, Universiti Malaya, faez_alhashimi@yahoo.com
} 


\section{PENDAHULUAN}

Fatwa merupakan salah satu instrumen yang penting bagi membantu perkembangan hukum Islam. Fatwa adalah suatu yang sentiasa berkembang selari dengan sifatnya yang sentiasa peka kepada kepelbagaian permasalahan yang berlaku dalam masyarakat. Justeru, dapat difahami bahawa perkembangan hidup semasa masyarakat akan memberi kesan terhadap kerencaman amalan berfatwa.

Kemajuan sosio ekonomi yang dicapai dalam masyarakat pada hari ini telah banyak mempengaruhi bentuk kegiatan ekonomi yang berlaku dalam kehidupan manusia. Zakat dan ekonomi saling mempunyai hubungan antara keduanya. Ia dilihat sebagai satu cabang ekonomi Islam yang turut memberi implikasi terhadap peningkatan sosio-ekonomi ummah. ${ }^{1}$ Selaras dengan itu, hasil daripada pengaruh perkembangan yang berlaku dalam masyarakat secara tidak langsung memberi kesan ke atas hukum zakat terutamanya menyentuh hal-hal yang berkaitan dengan pelaksanaannya seperti pungutan dan pengagihan. Kajian mengenai fatwa zakat di negeri Selangor memperlihatkan bagaimana fatwa telah memberi respons terhadap perkembangan yang berlaku dalam kegiatan ekonomi masyarakat Islam di negeri berkenaan.

\section{KEPENTINGAN MEMAHAMI REALITI SEMASADALAM BERFATWA}

Realiti semasa disebut sebagai الواقع di dalam bahasa Arab. Ia telah didefinisikan oleh beberapa ulama dengan pengertian yang tidak jauh berbeza. Antaranya Dr 'Abd al-Majīd al-Najār, beliau telah mendefinisikannya sebagai keadaan atau situasi yang melingkari kehidupan manusia. Ia sudah tentu akan menyentuh pelbagai perkara merangkumi segala aspek yang menyentuh kehidupan mereka. $^{2}$

1 Patmawati Hj Ibrahim, "Pembangunan Ekonomi Melalui Agihan Zakat: Tinjauan Empirikal", Jurnal Syariah 16 (Kuala Lumpur: Akademi Pengajian Islam, Universiti Malaya, 2008): 225.

2 Aḥmad Bū‘ūd, Fiqh al-Wāqi ‘ Ușūl wa Dawāäbiț (al-Qāhirah: Dār alSalām, 2006), 40. 
Pemahaman mengenai realiti semasa merupakan asas penting sebelum sesuatu fatwa dihasilkan kerana ia menggambarkan situasi dan keadaan yang sebenar bagi setiap persolan yang diajukan. Ini selaras dengan kaedah fiqh, تغيرّ الأحكام بتغيّر المكان والزمان iaitu hukum (fatwa) berubah akibat berubahnya tempat dan masa. Al-Qaraḍāwī dalam banyak penulisannya sangat menekankan kepentingan mengambil kira perubahan realiti masyarakat sebelum memutuskan sesuatu fatwa. ${ }^{3}$ Beliau telah menyebutkan bahawa kesalahfahaman terhadap realiti semasa akan menyebabkan berlakunya kesilapan dalam memberi fatwa. ${ }^{4}$ Pemahaman realiti sebenar ini penting dalam proses memberi fatwa. ${ }^{5}$ Ia telah diletakkan sebagai proses pertama yang dinamakan sebagai proses al-tașawwur. ${ }^{6}$ Menurut al-Qaraḍ̄āî lagi, penguasaan terhadap realiti semasa yang berlaku dalam kehidupan manusia memerlukan kajian dan penyelidikan mendalam yang dilakukan ke atas kehidupan mereka dari pelbagai aspek bagi mendapatkan gambaran realiti secara benar. ${ }^{7}$

Ibn al-Qayyim al-Jawziyyah di dalam kitabnya I'lām alMuwaqqi'in telah meletakkan bab Taghayyur al-Fatwā wa Ikhtilāfuhā bi Hasb Taghayyur al-Azminah wa al-Amkinah wa al-Ahwwāl wa al-Niyyāt wa al- 'Awā'id iaitu perubahan fatwa dan perbezaannya berdasarkan perubahan zaman, tempat, keadaan, niat dan adat juga menunjukkan perihal pentingnya asas ini dalam amalan berfatwa. ${ }^{8}$

3 Yūsuf al-Qaraḍāwī, Taysīr al-Fiqh li al-Muslim al-Mu 'āṣir fì Daw' al-Qurān wa al-Sunnah 1 (al-Qāhirah: Maktabah Wahbah, 1999), 37.

$4 \quad$ Al-Qaraḍāwī, Taysīr al-Fiqh, 57.

5 'Abd al-Raḥman Ibn Muhammad al-Dakhīl, al-Fatwā; Ahammiyyatuhā, Dawābițhā, Āthāruhā (Baḥth Muqaddam li Nayl Jā'izah Nāyif Ibn 'Abd al-'Azīz 'Alī Su'ūd al-'Ālamiyyah li Sunnah al-Nabawiyyah wa al-Dirāsāt al-Islāmiyyah al-Mu'āṣarah, 2007), 173.

6 Noor Naemah Abdul Rahman dan Muhammad al-Ghanim, "alMarāḥil al-Latī Tamurru bihā al-Fatwā”, Jurnal Al-Risalah, Vol VIII, Edisi 15, Nomor 1 (Jambi: IAIN Sultan Thaha Saifuddin Jambi, 2008): 107-115.

7 Aḥmad Bū‘ùd, Fiqh al-Wāqi`, 41.

8 Ibn al-Qayyim al-Jawziyyah, I'lām al-Muwaqqi'ìn 'an Rabb al'Ālamīn (al-Qāhirah: Dār al-Ḥadīth, 2006), 3 : 5. 
Melihat kepada sejarah pembinaan hukum Islam itu sendiri di zaman pembinaan mazhab misalnya. Kelahiran beberapa aliran mazhab utama yang empat adalah bukti pengaruh suasana dan adat resam setempat sehingga lahirnya aliran pemikiran hukum yang berbeza metodologinya. ${ }^{9}$ Kewujudan qawl qadìm dan qawl jadìd dalam mazhab Syafii juga menjelaskan kepentingan ini dalam berfatwa. Perpindahan Imam Syafii dari Iraq ke Mesir mendorong beliau mengubah pendapat yang telah diberinya semasa di Iraq kepada pendapat yang lebih sesuai di Mesir atas sebab meraikan perubahan realiti semasa yang berlaku ketika itu. ${ }^{10}$

\section{HUBUNGKAIT ANTARA AMALAN FATWA DENGAN REALITI SEMASA}

Fatwa dan perkembangan semasa saling berhubung kait antara satu sama lain. Apabila fatwa disifatkan sebagai jawapan hukum kepada persoalan yang berbangkit, maka perkembangan semasa yang berlaku adalah menjadi bahan penelitian dalam proses pengeluaran fatwa. Ibn al-Qayyim menyebutkan hal ini dengan jelas dengan mengatakan: "seorang mufti dan hakim tidak boleh memberi fatwa kecuali dengan menguasai 2 perkara utama, pertamanya ialah memahami realiti dan menguasainya dengan mendalam". ${ }^{11}$

Terdapat banyak faktor yang mempengaruhi realiti kehidupan manusia lantaran perkembangan semasa yang berlaku dalam kehidupan mereka. Perkembangan sains dan teknologi antara faktor pemangkin perubahan yang sangat mempengaruhi cara hidup masyarakat. Realiti dunia yang semakin maju hari ini

$9 \quad$ Ismail Mat, "Pengajian Syariah: Hubungannya dengan Adat Arab dan Keadaan di Malaysia", dalam Mahmood Zuhdi Ab Majid, Dinamisme Pengajian Syariah (Kuala Lumpur: Akademi Pengajian Islam, Universiti Malaya, 2001), 91-92.

10 'Abd al-Karīm Zaydān, al-Madkhal li Dirāsah al-Sharī'ah alIslāmiyyah (Bayrūt: Mu'assasah al-Risālah Nāshirūn, 2009), 196; Abdul Karim Ali dan Siti Kursiah Mansor, et al., "Faktor Perubahan Pendapat Imam Al-Shafi'i Dari Qawl Qadim Kepada Qawl Jadid”, dalam Jurnal Syariah 16, no. 2 (Kuala Lumpur: Akademi Pengajian Islam, Universiti Malaya, 2008): 308.

11 Ibn al-Qayyim, I'lām al-Muwaqqi 'ìn, $1: 77$. 
telah membuktikan banyak penemuan baru dalam bidang sains dan teknologi sama ada yang menyentuh bidang perubatan, komunikasi, maklumat dan sebagainya. Hasil perkembangan ini akan menimbulkan persoalan dan isu baharu yang memerlukan kepada penelitian dan kupasan hukum secara proaktif. ${ }^{12}$

Hukum Islam sama sekali tidak kaku dalam mendepani perkembangan yang berlaku. Malah dalam berdepan dengan fenomena ini, disiplin Ușūl al-Fiqh yang telah digariskan oleh para ulama berkeupayaan mengadaptasi realiti sosial yang timbul hasil daripada perubahan dan perkembangan yang berlaku. Konsep ijtihad dilihat telah membuka ruang yang luas dan sistematik khususnya bagi para ulama atau mufti dalam menyelesaikan permasalahan semasa yang dihadapi oleh umat Islam. ${ }^{13}$

Di Malaysia, meskipun dominasi mazhab Syafii dalam amalan fatwa masih berlaku namun demi meraikan tuntutan perkembangan semasa, laluan dibuka untuk mengambil pandangan di luar mazhab Syafii bahkan sampai kepada ijtihad yang lebih bebas telah diperuntukkan dalam enakmen negeri-negeri. Oleh itu, bagi menyelesaikan isu yang berbangkit dalam masyarakat jawatankuasa fatwa bebas untuk menentukan kaedah yang dilihat sesuai berasaskan keperluan dan tuntutan realiti semasa. ${ }^{14}$

Antara isu baharu yang menyentuh mengenai urusan zakat adalah berkaitan urusan pembayaran zakat, kemudahan kad kredit, perkhidmatan mesin ATM, kemudahan perhubungan menerusi internet yang telah membantu mempermudahkan urusan pembayaran zakat. Transaksi pembayaran zakatyang dibuat melalui medium-medium seperti ini dapat membantu melancarkan lagi

12 Anuar Zaini, "Kemajuan Sains dan Teknologi Kesannya Terhadap Perkembangan Hukum Islam Malaysia Masa Kini," dalam Raihanah Azahari dan Abdul Karim Ali, Hukum Islam Semasa (Kuala Lumpur: Akademi Pengajian Islam, Universiti malaya, 2001), 143.

13 Zulkiple Abd Ghani, "Teknologi Maklumat: Hubungannya Dengan Perkembangan Hukum Islam Semasa", dalam Raihanah Azahari dan Abdul Karim Ali, Hukum Islam Semasa, 148.

14 Noor Naemah Abdul Rahman, "Amalan Fatwa di Malaysia", dalam Jurnal Fiqh 4 (Kuala Lumpur: Akademi Pengajian Islam, Universiti Malaya, 2007): 89, URL: http://e-journal.um.edu.my/filebank/ published_article/3998/Amalan_Fatwa_di_Malaysia.pdf, diakses pada 16 April 2013, 
proses pengurusan zakat. Isu-isu lain seperti kaedah pembayaran zakat bagi KWSP, penubuhan syarikat-syarikat atau badan koperasi. Ahli jawatankuasa telah meneliti isu-isu seperti ini demi menjaga relevansi syariat di samping meraikan perkembangan yang berlaku dalam kehidupan masyarakat.

\section{FATWA JABATAN MUFTI NEGERI SELANGOR MENGENAI ZAKAT SEBAGAI RESPON KEPADA PERKEMBANGAN SEMASA}

Jabatan Mufti sebagai pihak yang bertanggungjawab secara langsung dengan aktiviti fatwa telah bertindak menjawab pelbagai persoalan dari berbagai pihak dalam masyarakat. Penelitian terhadap fatwa yang diputuskan oleh jabatan mufti negeri mendapati persoalan yang timbul adalah berbeza-beza dari tahun ke tahun. Tidak dinafikan ianya merupakan natijah daripada perkembangan semasa yang berlaku dalam masyarakat. Kajian yang dibuat terhadap fatwa dari tahun 2001-2011 mendapati, persoalan tersebut merangkumi pelbagai isu yang menyentuh bidang aqidah, ibadah, muamalat, munakahat, zakat, wakaf, pusaka, makan minum, perubatan dan banyak lagi. Berikut merupakan statistik pembahagian fatwa yang telah dikeluarkan mengikut bidang-bidang yang disebutkan.

Graf 1: Peratusan Kekerapan Fatwa-fatwa Negeri Selangor Mengikut Bidang

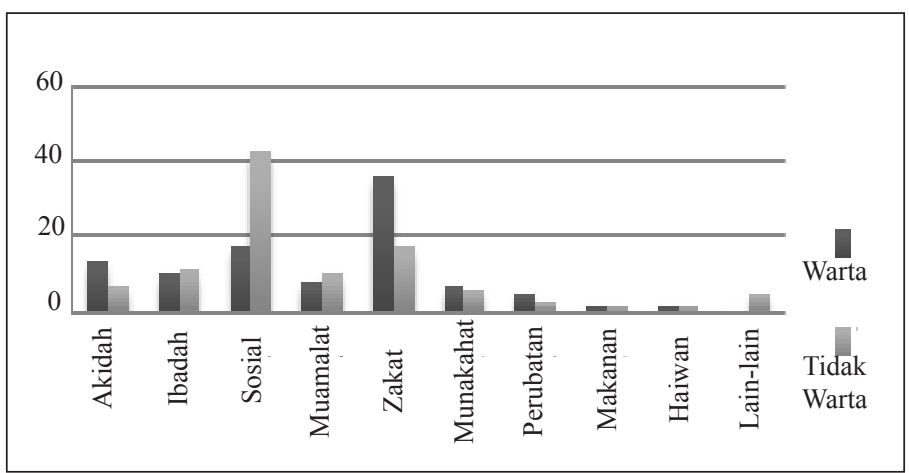

Sumber: Jabatan Mufti Negeri Selangor 
Statistik di atas merangkumi fatwa yang diwartakan dan juga yang tidak diwartakan. Bagi fatwa yang diwartakan, bidang zakat telah mencatatkan peratusan kekerapan tertinggi iaitu sebanyak $36.07 \%$ berbanding bidang-bidang yang lain. Adapun fatwa-fatwa yang tidak diwartakan mencatatkan kedudukan kedua tertinggi iaitu sebanyak $16.96 \%$. Lazimnya, persoalan zakat yang timbul dalam kalangan masyarakat akan dirujuk kepada pakar-pakar yang berkaitan dengan hal ehwal zakat seperti ahli dalam Lembaga Zakat Selangor. ${ }^{15}$

Carta 1: Peratusan Kekerapan Fatwa Tentang Zakat Mengikut Sub Bidang

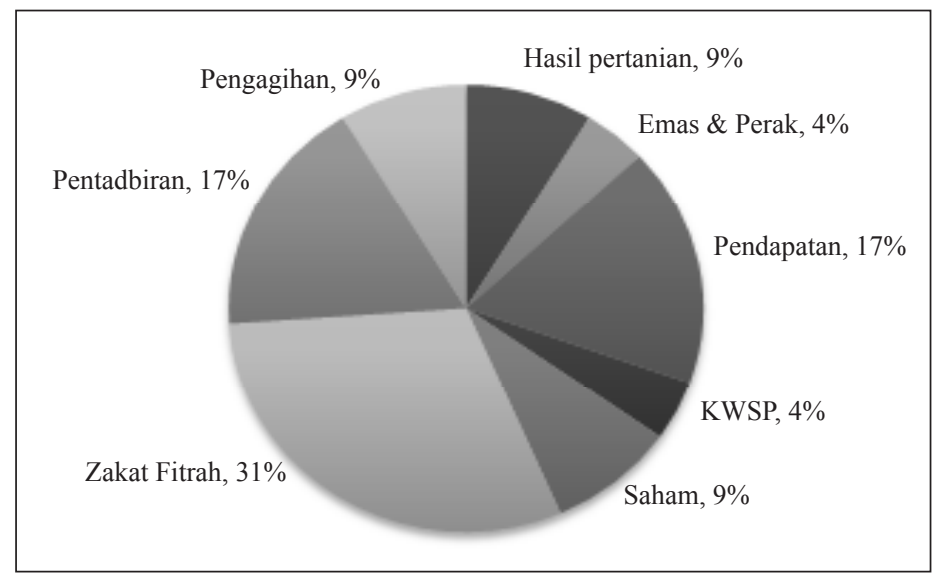

Sumber: Jabatan Mufti Negeri Selangor

Carta 1 di atas menunjukkan bahawa bilangan fatwa tentang zakat dan peratusan kekerapan pengeluarannya yang mana penganalisaannya dibuat berdasarkan sub bidang yang berkaitan. Hasil analisis mendapati terdapat 8 sub bidang yang berkaitan dengan zakat. Fatwa mengenai zakat fitrah adalah kerap sehingga mencecah $31 \%$ berbanding yang lain.

15 Nurhelmi Bin Ikhsan, Pegawai Perhubungan Awam Jabatan Mufti Negeri Selangor. Temubual pada 02 Mac 2012. 


\section{ANALISIS FATWA ZAKAT TERPILIH}

Berdasarkan sejumlah fatwa yang diputuskan, beberapa fatwa telah dipilih untuk dianalisis bagi memperlihatkan bagaimana fatwa dikemukakan sebagai respon kepada persoalan yang berbangkit dalam masyarakat. Antaranya adalah fatwa tentang kadar zakat fitrah, kadar zakat padi, kaedah pembayaran zakat KWSP, pembayaran zakat melalui perkhidmatan Maybank 2U dan kadar uruf emas perhiasan di negeri Selangor.

Justifikasi fatwa-fatwa tersebut dipilih untuk dianalisis adalah kerana fatwa tersebut lebih bersifat semasa dan menyentuh kepentingan masyarakat awam. Walaupun begitu, pemilihan ini tidak bermaksud menafikan fatwa yang lain tidak bersifat semasa dan menyentuh kepentingan semasa. Namun fatwa yang terpilih ini dilihat keutamaannya untuk dianalisis berasaskan kepentingan dan keberkesanan fatwa tersebut untuk dipraktikkan dalam masyarakat semasa hari ini. Oleh yang demikian, antara fatwafatwa yang dipilih untuk dianalisis adalah sebagaimana berikut:

\section{Fatwa tentang Harga Zakat Fitrah}

Jawatankuasa Fatwa Negeri Selangor (JFNS) telah menetapkan kadar harga zakat fitrah yang perlu dibayar oleh semua umat Islam yang tinggal atau bekerja di negeri Selangor. Berikut merupakan kadar harga yang telah ditetapkan oleh jawatankuasa berkenaan sepanjang tempoh sepuluh tahun seperti jadual di bawah:

Jadual 1: Kadar Harga Zakat Fitrah bagi Tahun 2001 (1422H) hingga 2011 (1432H)

\begin{tabular}{|c|c|}
\hline TAHUN & HARGA ZAKAT FITRAH (RM) \\
\hline $2001(1422 \mathrm{H})$ & 4.20 \\
\hline $2002(1423 \mathrm{H})$ & 4.50 \\
\hline $2003(1424 \mathrm{H})$ & 4.50 \\
\hline $2004(1425 \mathrm{H})$ & 4.70 \\
\hline $2005(1426 \mathrm{H})$ & 4.70 \\
\hline $2006(1427 \mathrm{H})$ & 4.70 \\
\hline $2007(1428 \mathrm{H})$ & 5.20 \\
\hline $2008(1429 \mathrm{H})$ & 5.20 \\
\hline
\end{tabular}




\begin{tabular}{|l|l|}
\hline $2009(1430 \mathrm{H})$ & 7.00 \\
\hline $2010(1431 \mathrm{H})$ & 7.00 \\
\hline $2011(1432 \mathrm{H})$ & 7.00 \\
\hline
\end{tabular}

Sumber: Lembaga Zakat Selangor

Cadangan penetapan kadar harga zakat fitrah bagi negeri Selangor telah disediakan oleh Lembaga Zakat Selangor (MAIS) yang kemudiannya dikemukakan kepada JFNS bagi mendapatkan pandangan, pengesahan dan persetujuan. Penelitian terhadap jadual di atas menunjukkan perbezaan kadar telah berlaku. Perbezaan harga sebanyak RM 0.30 telah berlaku antara tahun 2001 dan 2002, perbezaan RM 0.20 pada tahun 2003 dan 2004. Manakala tahun 2007 dan 2006 berlaku perubahan harga dengan perbezaan sebanyak RM 0.50. Seterusnya perbezaan yang tinggi telah berlaku antara tahun 2008 dan 2009 dengan tiga tahun berikutnya iaitu sebanyak RM 1.80. Sepanjang tempoh sepuluh tahun ini juga memperlihatkan kenaikan kadar harga zakat fitrah yang berlaku sekitar dua atau tiga tahun sekali melainkan tetapan kadar pada tahun 2001 (1422H).

Perbezaan tersebut merupakan kesan daripada perubahan harga runcit beras tempatan mengikut kawasan tertentu. Pihak Kementerian Pertanian dan Industri Asas Tani Malaysia, Bahagian Industri Padi dan Beras akan mengeluarkan senarai harga runcit beras di pasaran semasa untuk dijadikan rujukan dan panduan pihak LZS dalam menentukan kadar harga zakat fitrah tahunan. ${ }^{16}$ Keputusan fatwa tersebut dilihat sebagai keputusan yang telah dibuat dengan mengambil kira faktor perkembangan semasa yang berlaku.

Jawatankuasa yang telibat dalam memutuskan ketentuan kadar harga zakat telah mengguna pakai kaedah fiqh العادة محكمة, iaitu adat boleh menjadi penentu hukum syarak. ${ }^{17}$ Oleh kerana beras merupakan makanan asasi bagi penduduk Islam di Malaysia amnya dan Selangor khususnya, maka kebiasaan (العادة) tersebut

\footnotetext{
16 Mesyuarat Jawatankuasa Fatwa Negeri Selangor Kali Ke 1/2011, Kertas Kerja Bil. 3/1/2011, Jabatan Mufti Negeri Selangor.

17 Jamāl al-Dīn al-Suyūțî, al-Ashbah wa al-Nazā’ir fì Qawā'id wa Furū' Fiqh al-Shāfi 'iyyah (Mișr: Mușțafā al-Bābī al-Ḥalab̄̄ wa Awlāduhu, 1938), 91.
} 
diambil kira bagi menentukan barangan yang digunakan untuk mengeluarkan zakat fitrah bagi negeri Selangor.

Kaedah fiqh ini juga diguna pakai dalam persampelan jenis beras yang digunakan sebagai ukuran untuk menetapkan kadar harga zakat fitrah bagi negeri Selangor. Terdapat pelbagai jenis beras yang telah dikeluarkan oleh syarikat yang berbeza dan dijual dengan harga yang berbeza di pasaran sebagai makanan asasi umat Islam di Selangor. Contohnya beras Super Special Tempatan, Super Tempatan, Basmathi, Wangi AAA, beras pulut dan beras hancur. ${ }^{18}$ Oleh kerana beras jenis Super Tempatan menjadi pilihan utama masyarakat di Selangor, ${ }^{19}$ maka kebiasaan (العادة) tersebut diambil kira untuk menentukan harga beras yang dijadikan sebagai asas bagi penetapan harga zakat fitrah di Selangor.

Manakala dari segi kadar yang perlu dikeluarkan adalah tetap iaitu $1 s \bar{a}^{\prime}{ }^{20}$ Seperti mana yang telah disebutkan dalam hadis Rasulullah SAW.

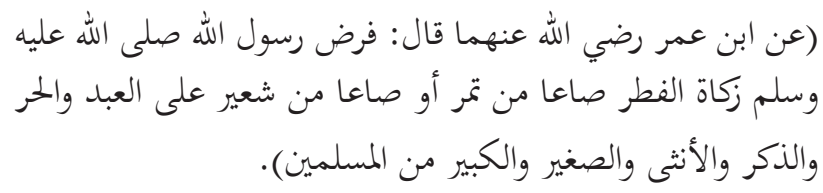

Maksudnya:

Rasulullah SAW mewajibkan zakat fitrah sebanyak satu șā' kurma, atau satu șā' gandum kepada hamba atau merdeka, lelaki mahupun wanita, kecil ataupun besar di antara kaum Muslimin. ${ }^{21}$

Kadar ini tidak akan mengalami perubahan dengan perubahan masa dan keadaan. Bahkan ia dijadikan sebagai kayu ukur dalam penentuan kadar yang perlu dikeluarkan tetapi nilaiannya

18 Padiberas Nasional Berhad (BERNAS), http://www.bernas.com.my/ index.php?option $=$ com_content $\&$ view $=$ article $\&$ id $=68$ :rice-types-in malaysia\&catid=47:ricepedia, diakses pada 20 April 2012.

19 Mesyuarat Jawatankuasa Fatwa Negeri Selangor Kali Ke 1/2011.

$201 s \bar{a}^{\mathrm{a}}$ bersamaan 2.7 kilogram.

21 Muhammad Ibn Ismā'il al-Bukhārī, Șah̄̄h al-Bukhārī, Kitāb alZakāt, Bāb Șadaqadat al-Fițr, no. hādīth: 1503 (Riyāọ: Maktabah alRushd, 2006), c. 2, $1: 460$. 
terhenti pada perkiraan semasa. Berikut dibawakan contoh kaedah pengiraan harga zakat fitrah negeri Selangor bagi tahun 1432H/2011M iaitu harga beras Super Tempatan berdasarkan berat satu gantang Baghdad atau 2.7 kilogram:

\section{$R M 2.60$ sekilogram $X 2.7$ kilogram $=R M 7.02 / R M 7.00$}

Justeru itu, kelihatan Jawatankuasa Fatwa Negeri Selangor apabila mendepani persoalan penentuan kadar harga bagi zakat fitrah negeri Selangor, telah mengambil kira realiti yang berlaku. Pertamanya dari segi jenis barangan yang digunakan untuk mengeluarkan zakat fitrah, jenis beras yang digunakan untuk menentukan kadar harga zakat yang perlu dikeluarkan dan harga beras tersebut dalam pasaran semasa.

\section{Fatwa tentang Harga Zakat Padi}

Pada tahun 2001, JFNS telah menetapkan bahawa kadar zakat padi ialah 5\% daripada hasil pendapatan kasar tanpa menolak kos pengeluaran. Ini kerana dalam penanaman padi, para petani perlu mengeluarkan kos yang tinggi termasuk perkhidmatan air dan jentera untuk mendapatkan hasil yang baik dan lumayan. ${ }^{22}$

Persoalan ini dibangkitkan oleh pihak LZS yang berhasrat supaya masyarakat petani yang tinggal di Selangor mengeluarkan zakat tanaman padi. Di Selangor, antara daerah yang menjadi tumpuan penanaman padi adalah daerah Tanjung Karang dan Sabak Bernam. Justeru, masyarakat petani di kawasan tersebut menjadi fokus utama dalam menyeru mereka supaya mengeluarkan zakat tanaman padi. ${ }^{23}$

Persoalan mengenai penetapan kadar bagi zakat padi ini timbul berikutan ke tidakseragaman penyampaian maklumat zakat padi dan penerangannya secara menyeluruh kepada kebanyakan petani di beberapa kawasan negeri Selangor yang tidak mengeluarkan

22 e-fatwa, Portal Rasmi Fatwa Malaysia, http://www.e-fatwa.gov. my/fatwa-negeri/fatwa-tentang-harga-zakat-padi, di akses pada 21 Februari 2013.

23 Kertas Cadangan Penetapan Kadar Zakat Untuk Zakat Padi, Pusat Zakat Selangor (MAIS), 2001. 
zakat. ${ }^{24}$ Timbul perbezaan pandangan dalam kalangan masyarakat hingga sebahagiannya berpandangan bahawa zakat padi dibayar $10 \%$ daripada pendapatan setelah di tolak kos penghasilan sementara sebahagian yang lain pula berpendapat $5 \%$ daripada pendapatan kasar. Bahkan terdapat juga sebilangan petani mengeluarkan zakat mereka dengan cara mereka sendiri tanpa merujuk kepada dua pandangan tadi. ${ }^{25}$

Dalam membincangkan persoalan kadar pengeluaran zakat dari hasil tanaman, para fuqaha telah menjelaskan bahawa zakat yang perlu dipungut daripada hasil tanaman yang diperolehi ialah $10 \%$ atau $5 \%$. Sekiranya tanaman berkenaan menggunakan sistem pengairan menerusi sumber alam seperti air hujan, parit ataupun kemudahan air sedia ada yang lain, maka zakat perlu dikeluarkan $10 \%$ daripada hasil perolehan tanaman. Manakala $5 \%$ sekiranya tanaman menggunakan sistem pengairan yang banyak menggunakan tenaga manusia seperti mengangkat air dan seumpamanya. ${ }^{26}$

Ketetapan ini adalah berdasarkan kepada hadis Rasulullah SAW:

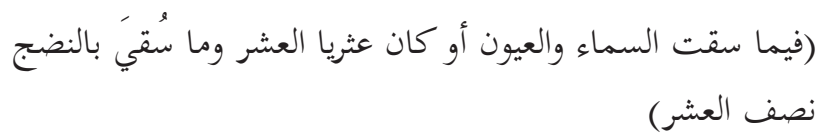

Maksudnya:

Pada apa tanaman yang dialiri dengan air hujan atau dengan mata air, atau takungan, zakatnya adalah 1/10 (10\%), sedangkan yang dialiri dengan tenaga penyiram zakatnya adalah 1/20 (5\%). ${ }^{27}$

24 Kertas Cadangan Penetapan Kadar Zakat Untuk Zakat Padi, Pusat Zakat Selangor (MAIS), 2001.

25 Mujaini Tarimin, Zakat Pertanian: Sistem dan Pelaksanaannya (Selangor: Dewan Bahasa dan Pustaka,1990), 59.

26 Wahbah al-Zuhaylī, al-Fiqh al-Islāmō wa Adillatuh (Damshiq: Dār al-Fikr, 1989), 2 : 812; al-Baghawī, al-Tahdhīb fi Fiqh al-Imām alShāfi 'i (Lubnan: Dār al-Kutub al-'Ilmiyyah,1997), 3 : 91.

27 Al-Bukhārī, Șah̄ịh al-Bukhārī, Kitāb al-Zakāt, Bāb al-'Ushur fī mā Yusqā min Mā' al-Samā' wa bi al-Mā' al-Jārī, no. ḥadīth: 1483, 1 : 460. 
Al-Qaraḍāwī di dalam Fiqh al-Zakāh ada menukilkan penjelasan ulama seperti Abū 'Ubayd mengenai hadis di atas menerusi al-Rawḍah oleh al-Imām al-Nawāwī, Ibn Hajar dalam al-Talkhis s. Beliau telah menyimpulkan bahawa kadar zakat yang perlu dikeluarkan sama ada $5 \%$ atau $10 \%$ adalah berasaskan kepada sistem pengairan dalam pengusahaan tanaman. ${ }^{28}$

Dalam realiti masyarakat hari ini, pelbagai usaha dilakukan bagi memperoleh hasil tanaman yang banyak dan lumayan. Para petani akan mengeluarkan kos-kos lain termasuk harga biji benih, baja, racun, upah membajak, upah membersih parit atau batas, upah memungut hasil dan sebagainya. Justeru, terdapat perbincangan lain apakah kos-kos sampingan seperti ini perlu ditolak terlebih dahulu sebelum hasil tanaman itu dizakatkan.

Sebenarnya telah wujud perbincangan berkenaan keperluan menolak kos pengeluaran selain kos sistem pengairan tanaman sahaja. Mahmood Zuhdi Ab Majid menerusi bukunya Pengurusan Zakat telah membawakan perbahasan terperinci mengenai persoalan ini. Beliau telah menukilkan pendapat Ibn Hazm yang menyatakan bahawa terdapatnya perbezaan pandangan fuqaha. Sebahagiannya berpendapat hendaklah ditolak perbelanjaan terlebih dahulu sebelum dibuat pengiraan untuk dikeluarkan zakat. Pandangan ini telah dikemukakan oleh 'Ațā. Sementara terdapat pula pendapat lain yang mengatakan semua hasil tanaman hendaklah dizakatkan tanpa ditolak kos terlebih dahulu. Pendapat ini dikemukakan oleh oleh Imam Malik, Syafii dan Abu Hanifah dan menjadi pandangan pilihan oleh Ibn Hazm sendiri. ${ }^{29}$

Menurut al-Qaraḍāwī, kos bagi sistem pengairan masih menggunakan kaedah pengeluaran sama ada $5 \%$ atau $10 \%$, di samping keperluan untuk dilakukan tolakan terlebih dahulu terhadap kos-kos sampingan lain termasuk keperluan diri dan tanggungan hutang sebelum zakat tersebut dikeluarkan. Beliau telah menukilkan bahawa Ibn 'Arabī dalam Sharh al-Tirmìdhī

28 Yūsuf al-Qaraḍāwī, Fiqh al-Zakāt (al-Qāhirah: Maktabah Wahbah, 2006), 1 : 386-387.

29 Mahmood Zuhdi Ab Majid, Pengurusan Zakat (Kuala Lumpur: Dewan Bahasa dan Pustaka, 2003), 278. 
telah membincangkan persoalan ini dengan lebih jauh dan mempunyai pendapat yang hampir sama dengan beliau. ${ }^{30}$

Justeru, berdasarkan keputusan fatwa yang telah dikeluarkan oleh jawatankuasa fatwa dalam permasalahan ini, penetapan kadar yang pada dasarnya $10 \%$ diturunkan penetapannya kepada kadar 5\% kerana banyak menggunakan kos dan tenaga dalam proses pengeluaran. Penetapan kadar sebanyak 5\% tersebut adalah dikeluarkan daripada pendapatan kasar tanpa mengambil kira kos-kos perbelanjaan lain seperti kos membaja dan meracun. Berdasarkan kadar yang telah ditetapkan tersebut juga, zakat padi boleh dikeluarkan berasaskan nilai atau wang.

Penulis melihat, dengan mengambil kira faktor semasa masyarakat, keputusan fatwa ini merupakan satu inisiatif positif untuk meningkatkan kesedaran masyarakat dalam masalah ini dan galakan supaya zakat dikeluarkan. Namun begitu, penetapan kadar sebanyak 5\% tersebut perlu dilakukan penelitian. Apakah penetapannya semata-mata berdasarkan kepada cara pengairan dan kos-kos yang berkait rapat untuk tujuan tersebut. Sejauh manakah kewajaran tidak perlu dilakukan penolakan terhadap kos-kos sampingan lain sehingga penetapan kadar 5\% menjadi kaedah pengiraan bagi zakat padi yang dipilih oleh jawatankuasa terbabit.

\section{Fatwa tentang Kaedah Pembayaran Zakat KWSP}

Pada tahun 2001 Jawatankuasa Fatwa Negeri Selangor telah membuat keputusan berkenaan kaedah pembayaran zakat KWSP seperti berikut: ${ }^{31}$

i) Apabila menerima wang KWSP, seseorang hendaklah menunggu setahun bagi mencukupi haul barulah dikeluarkan zakat $2.5 \%$, atau

\footnotetext{
30 Al-Qaraḍ̄wī, Fiqh al-Zakāt, 1 : 403.

31 e-fatwa, Portal Rasmi Fatwa Malaysia, http://www.e-fatwa.gov. my/fatwa-negeri/fatwa-tentang-kaedah-pembayaran-zakat-kwsp, di akses pada 21 Februari 2013.
} 
ii) Apabila menerima wang KWSP, seseorang bolehlah terus mengeluarkan zakat 2.5\% tanpa menunggu tempoh setahun kerana dikhuatiri wang tersebut akan berkurangan dari segi nisabnya yang tidak wajib dikenakan zakat lagi.

Berdasarkan fatwa yang telah diputuskan, terdapat dua pilihan dalam kaedah pembayaran zakat KWSP sama ada menunggu atau tidak menunggu tempoh haul setahun. Penulis berpandangan, penetapan fatwa dalam bentuk memberi pilihan kepada para pembayar zakat adalah satu penyesuaian terhadap realiti semasa yang berlaku. Ia adalah satu usaha bagi mengelak pemilik wang KWSP daripada meninggalkan kewajipan zakat apabila mereka menangguhkan pengeluaran zakat KWSP.

Pada tahun 2007 satu fatwa telah diputuskan yang dilihat sebagai kesinambungan daripada fatwa yang telah diputuskan pada tahun 2001. Jawatankuasa fatwa telah memutuskan bahawa: ${ }^{32}$

"Pencarum KWSP digalakkan mengeluarkan zakat sejurus menerima atau mengeluarkan wang KWSP tersebut jika cukup nisabnya tanpa menunggu haul setahun".

Secara umumnya, kelihatan majoriti masyarakat lebih selesa membayar terus $2.5 \%$ daripada jumlah wang KWSP yang diterima ${ }^{33}$ sama ada pengeluaran wang tersebut digunakan sebagai deposit membeli rumah atau menerima sebahagian kecil ketika berumur 50 tahun atau menerima keseluruhannya apabila pencen bekerja. Justeru, kaedah pembayaran kedua iaitu tanpa perlu menunggu haul setahun yang diletakkan sebagai kaedah pilihan adalah wajar sebagaimana penetapannya dalam keputusan fatwa pada tahun 2007.

Wang simpanan KWSP adalah dikategorikan sebagai al-Māl al-Mustafäd iaitu wang tersebut terhasil daripada upah pekerjaan. Oleh yang demikian, zakat perlu dikeluarkan daripada harta perolehan seperti ini selepas cukup nisab dan haul. Merujuk kepada peraturan yang telah ditetapkan oleh kerajaan demi

32 Lembaga Zakat Selangor, http://www.e-zakat.com.my/fatwa-negeriselangor/, di akses pada 21 Februari 2013.

33 Kertas Mesyuarat 1/1/2000, Kertas Cadangan Menentukan Satu Kaedah Tetap Bagi Zakat KWSP, Pusat Zakat Selangor (MAIS). 
menjamin masa depan dari sudut kewangan pekerja, bayaran tersebut ditangguhkan pada masa tertentu dengan syarat-syarat tertentu. Zakat KWSP termasuk dalam kategori harta zakat yang dikenakan syarat haul. Perbincangan ini melibatkan persoalan berkenaan syarat cukup tempoh haul.

Mengenai syarat haul, majoriti fuqaha termasuk ulama Shāfi'iyyah berpandangan zakat boleh dikeluarkan lebih awal daripada waktu yang sepatutnya melainkan harta yang masih belum cukup nisab. ${ }^{34}$ Abū 'Ubayd menerusi Kitāb al-Amwāl ada menyebutkan bahawa berdasarkan kepada riwayat-riwayatnya menunjukkan tindakan menunaikan zakat sebelum cukup tempoh haulnya adalah baik. ${ }^{35}$

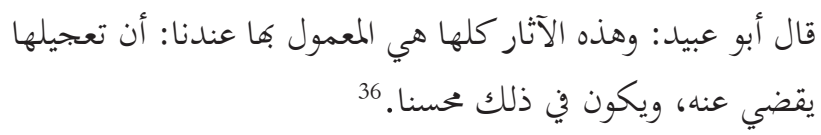

Pada hakikatnya, haul bagi wang simpanan KWSP telah bermula apabila jumlah simpanan telah genap setahun. Justeru apabila haul telah genap setahun sewajarnya zakat bagi simpanan KWSP tersebut dibayar, tetapi memandangkan pengeluarannya hanya dibenarkan berdasarkan syarat-syarat tertentu, maka zakat KWSP tersebut tertangguh perlaksanaannya sehinggalah berlalu haul tersebut dan haul yang selepasnya sehinggalah wang tersebut dikeluarkan. ${ }^{37}$

Antara kaedah pendekatan yang dikenal pasti ialah kaedah iaitu kesukaran dapat menarik kemudahan. ${ }^{38}$

34 Wahbah al-Zuhaylī, al-Fiqh al-Islāmī wa Adillatuh, 756; Mușțafā al-Khin et al. al-Fiqh al-Manhajī (Damshiq: Dār al-Qalam, 2000), 315; Muḥy al-Dīn al-Nawaw̄in, Minhāj al-Ṭālibīn (Bayrūt: Dār alBashā'ir al-Islāmiyyah, 2000), 1 : 409. Termasuk pandangan yang dikemukakan oleh al-Qaraḍāwī, lihat: al-Qaraḍāwī, Fiqh al-Zakāt, 2: 834 .

35 Abū 'Ubayd al-Qāsim Ibn Salām, Kitāb al-Amwāl (Bayrūt: Dār alShurūq, 1989), 699.

36 Abū 'Ubayd, Kitāb al-Amwāl, 700.

37 Kertas Kerja Bil. 6/5/06, Bayaran Zakat KWSP Sejurus Pengeluaran Satu Altenatif, Jabatan Mufti Negeri Selangor.

38 Muhammad al-Zarqā, Sharh al-Qawā'id al-Fiqhiyyah (Damshiq: Dār al-Qalam, 1998), 2 : 157. 
Dalam pembayaran zakat KWSP ini, menjadi kesukaran kepada masyarakat umumnya untuk membayar zakat KWSP mengikut tahun-tahun berlalu. Antaranya mereka terpaksa mendapatkan semula segala penyata dan akhirnya ditakuti akan timbul pula masalah malas, maka zakat pun tidak dikeluarkan. Namun begitu, masyarakat lebih memilih membayar terus $2.5 \%$ daripada jumlah wang KWSP. Kaedah ini lebih baik daripada mereka langsung tidak mahu membayarnya. Justeru dalam penetapan satu-satu kaedah tidak perlu terlalu sempit sehingga menyukarkan masyarakat untuk melaksanakannya.

Antara prinsip qawā'id fiqh lain yang dilihat selari dengan penetapan kaedah pembayaran zakat ini ialah المتعدي أفضل من iaitu amal yang mempunyai impak positif yang luas lebih baik daripada amal yang impaknya terbatas. ${ }^{39}$ Ketika mana wang KWSP diterima, rata-rata kebanyakan umat Islam akan membayar terus $2.5 \%$. Kelihatannya cara ini adalah lebih sesuai, mudah dan berkesan untuk dilaksanakan demi menanam kesedaran tentang wajibnya mengeluarkan zakat dalam diri masyarakat.

Oleh yang demikian, fatwa ini adalah wajar dengan kesinambungan fatwa yang telah dikeluarkan pada tahun 2007 sebagai fatwa yang lebih jelas. Para pembayar tidak lagi keliru dan tertanya-tanya mengenai hukum yang berkaitan dengan ibadah yang ingin dilakukan. Justeru, fatwa yang telah dikeluarkan adalah sebagai respon terhadap realiti masyarakat yang berlaku.

\section{Fatwa tentang Pembayaran Zakat Melalui Pembayaran Elektronik}

Fatwa berhubung kaedah pembayaran zakat melalui pembayaran elektronik adalah wajar dan dilihat telah meraikan perkembangan realiti semasa yang berlaku. Ini kerana, antara faktor yang memberi kesan terhadap perkembangan ini adalah kemajuan dalam bidang sains dan teknologi. Persoalan ini kemungkinan timbul atas beberapa sebab seperti lokasi kaunter pembayaran zakat yang terletak jauh daripada rumah atau pejabat. Apatah lagi mereka yang tinggal di kawasan bandar yang terpaksa berhadapan

39 Al-Suyūṭī, al-Ashbah wa al-Naẓā'ir, 311. 
dengan kesesakan lalu lintas di samping kesuntukan masa dengan komitmen kerja.

Pada tahun 2011, Jawatankuasa Fatwa Negeri Selangor telah memutuskan bahawa pembayaran zakat fitrah dengan menggunakan kaedah elektronik adalah diharuskan. ${ }^{40}$ Keputusan ini telah merubah keputusan hukum yang telah dibuat pada tahun 2002 iaitu pembayaran zakat melalui perkhidmatan Maybank 2U (internet) adalah harus bagi zakat harta sahaja dan tidak termasuk zakat fitrah. $^{41}$

Pembayaran tanpa tertumpu hanya di kaunter-kaunter zakat merupakan satu usaha pihak LZS supaya hal-hal yang berkaitan dengan pengurusannya lebih mudah dan cekap. Perkembangan teknologi ini telah menyumbang kepada kemudahan kaedah pembayaran zakat bersesuaian dengan prinsip-prinsip hukum Islam. Antaranya pembayaran zakat melalui sistem perbankan dilihat menepati syarat penyertaan niat sewaktu pembayaran. Niat merupakan perkara yang disepakati oleh para ulama sebagai sesuai yang wajib dalam pengeluaran zakat. ${ }^{42}$ Jumhur ulama berpendapat, tidak sah zakat tanpa niat. ${ }^{43}$

Justeru, dalam kaedah pembayaran elektronik ini, penyertaan niat sewaktu pembayaran zakat dilakukan tidak menjadi persoalan. Ini kerana setiap pembayar sudah semestinya akan menyertakan niat untuk membayar zakat sewaktu menekan butang komputer yang menunjukkan bahawa ia bersetuju untuk membayar zakat. Sebagaimana menurut Imam Syafii, niat yang dilafazkan tidak menjadi syarat terhadap sahnya pembayaran zakat. ${ }^{44}$

40 Lembaga Zakat Selangor, http://www.e-zakat.com.my/fatwa-negeriselangor/, di akses pada 21 Februari 2013.

41 Lembaga Zakat Selangor, http://www.e-zakat.com.my/fatwa-negeriselangor/, di akses pada 21 Februari 2013.

42 Al-Zuhaylī, al-Fiqh al-Islāmī, 750.

43 Abū Ishạā al-Shīrāzī, al-Muhadhdhab (Bayrūt: Dār al-Kutub al'Ilmiyyah, 1995), 1 : 311; Ibn Qudāmah, al-Mughnī, cet. 5 (Riyāḍ: Dār 'Ālim al-Kutub, 2005), 4 : 88. 'Abd al-Raḥman al-Jazīīi, alFiqh 'alā a-Madhāhib al-Arba'ah (Qāhirah: Dār al-Hadīth, 2004), 1: 458.

44 Al-Shīrāzī, al-Muhadhdhab, 1 : 751. 
Pembayaran zakat merupakan suatu kewajipan yang tidak memerlukan akad iaitu ijab dan qabul dan tidak memberi kesan terhadap sahnya pembayaran. Namun begitu, pihak Maybank tetap akan memaparkan akad tersebut di hadapan skrin komputer dan pembayar boleh membaca akad tersebut dan ia juga diterima sebagai akad yang $s a{ }^{45}$ bertepatan dengan kaedah fiqhiyyah yang ada menyebut الكتاب كالخطاب iaitu tulisan itu dianggap sebagai percakapan di dalam akad. ${ }^{46}$

Pembayaran zakat dengan menggunakan kaedah seperti ini dilihat lebih berkesan dengan memberikan berbagai kemudahan pembayaran zakat kepada orang ramai yang mana semakin ramai orang menunjukkan minat menggunakan kaedah ini. Ini dibuktikan dengan berdasarkan kepada statistik yang dikeluarkan oleh Lembaga Zakat Selangor bahawa hasil kutipan daripada pembayaran zakat harta yang telah menyumbang sebanyak RM 3.17 juta pada tahun 2007 berbanding hanya RM 1.9 juta pada tahun $2006 .{ }^{47}$

Transaksi yang dijalankan adalah secara elektronik termasuk penyaluran wang ke akaun zakat LZS. Justeru melalui kaedah ini tiada transaksi fizikal wang yang terlibat. Ini pastinya meningkatkan kecekapan pengurusan zakat itu sendiri. Keputusan hukum ini dilihat telah menyumbang kepada kemaslahatan pembayar zakat malahan pihak badan yang bertanggungjawab dalam pengurusan zakat.

Selain itu, merujuk kepada fatwa yang telah dikeluarkan ini juga dilihat meraikan prinsip qawā’id fiqh المشقة بحلب التيسير iaitu kesulitan itu membawa kepada kemudahan. ${ }^{48}$ Pembayaran melalui kaedah ini dilihat membantu memberi kemudahan kepada orang ramai untuk melaksanakan kewajipan ini tanpa keterbatasan pergerakan, masa dan sebagainya. Justeru itu, dapat penulis simpulkan bahawa fatwa yang telah diputuskan ini adalah relevan dengan realiti yang berlaku kini.

45 Kertas Mesyuarat 1/1/2001, Pembayaran Zakat Melalui Perkhidmatan Maybank 2U (Internet), Pusat Zakat Selangor.

46 Al-Zarqā, Sharh al-Qawā 'id al-Fiqhiyyah, 2 : 349.

47 Kertas Kerja Cadangan PembayaranZakatFitrah Melalui Pembayaran Elektronik, 2011, Lembaga Zakat Selangor.

48 Ibid. 


\section{Fatwa tentang Kadar Uruf Emas Perhiasan di Negeri Selangor}

Jawatankuasa Fatwa Negeri Selangor pada tahun 2005, telah menetapkan bahawa 'Kadar uruf emas perhiasan di negeri Selangor adalah pada timbangan $800 \mathrm{gm}$. Mana-mana timbangan yang melebihi kadar uruf emas perhiasan adalah diwajibkan zakat perhiasan sepenuhnya, tanpa mengecualikan nilai yang di bawah adat atau uruf. ${ }^{49}$

Fatwa yang telah diputuskan oleh jawatankuasa seperti di atas kelihatan menangani realiti semasa yang berlaku. Persoalan mengenai kadar penetapan seperti ini timbul ekoran perubahan penggunaan masyarakat terhadap perhiasan emas yang sifatnya sentiasa berubah dari masa ke semasa kesan daripada perubahan latar belakang dan budaya masyarakat.

Secara umumnya, para fuqaha berbeza pendapat dalam kewajipan zakat ke atas emas perhiasan. Terutamanya bagi emas perhiasan yang dipakai. Ada sebahagian yang berpendapat wajib zakat seperti ulama Hanafiyyah. ${ }^{50}$ Manakala sebahagiannya yang lain tidak mewajibkannya. Pandangan ini mewakili ulama Mālikiyyah, ${ }^{51}$ Shāfi 'iyyah ${ }^{52}$ dan Hanābilah. ${ }^{53}$ Namun begitu, ketidakwajipan tersebut menurut pandangan golongan tersebut tidaklah secara mutlak. Sekiranya pemakaian emas perhiasan itu melebihi kadar uruf masyarakat di kawasan tertentu, maka

49 Lembaga Zakat Selangor, http://www.e-zakat.com.my/fatwa-negeriselangor/, di akses pada 22 Februari 2013.

50 'Alā' al-Dīn Abī Bakr Ibn Mas ‘ūd al-Kāsānī al-Hanafī, Badā 'i ‘ alSanā 'i'fì Tartīb al-Sharā' 'i (tahqīq: 'Alī Muhammad Mu'awwad), (Bayrūt: Dār al-Kutub al-'Ilmiyyah, 2003), 3 : 407.

51 Mālik Ibn Anas, Muwațtā' al-Imām Mālik (tahqīq: Taqi al-Dīn alNadwī), (Damshiq: Dār al-Qalam, 2005), c. 4, 2 : 140.

52 Ibn Idrīs al-Shāfi' $\overline{1}$, al-Umm (Bayrūt: Dār al-Kutub al-'Ilmiyyah, 1993), $2: 55$.

53 Ibn Qudāmah, al-Mughn̄̄, 4 : 220; 'Alā' al-Dīn Abī al-Husayn 'Alī Ibn Sulaymān al-Mārdawī, al-Inșāf (Bayrūt: Dār Iḥyā' al-Turāth al-'Arabī, 1998), 3 : 100. Lihat juga al-Zuhaylī, al-Fiqh al-Islāmī wa Adillatuh, 765; Aḥmad Muhammad al-Qaddurī, Mawsū'ah alQawā 'id al-Fiqhiyyah al-Muqāranah (al-Tajrīd) (al-Qāhirah: Dār al-Salām, 2004), 3 : 1323. 
zakat tidak gugur ke atasnya. Di Malaysia telah mengaplikasi pandangan yang menyatakan zakat wajib dikeluarkan ketika mana pemakaiannya melebihi kadar nisab yang diputuskan oleh setiap negeri masing-masing.

Begitu juga menurut al-Qaraḍāwī, sebarang perhiasan yang melebihi kadar kebiasaan maka wajib dizakatkan. ${ }^{54}$ Selain itu, fatwa yang pernah dikeluarkan oleh Shaykh 'Alī Jum'ah juga selari dengan pendapat tersebut. ${ }^{55}$ Shaykh Muștafā al-Zarqā di dalam kitabnya Fatā $w \bar{a}^{56}$ dan juga para ulama dari negara Arab Saudi menerusi himpunan fatwa-fatwa juga memberikan jawapan yang sama dalam persoalan ini. ${ }^{57}$

Antara asas pertimbangan penting yang digunakan adalah kaedah dalam fiqh iaitu العادة محكمة iaitu adat boleh menjadi penentu hukum syarak. Latar belakang masyarakat di satu kawasan adalah berbeza-beza yang mana dipengaruhi oleh persekitaran semasa, budaya atau cara hidup.

Sekiranya emas yang dipakai melebihi had kebiasaan atau uruf perhiasan, maka akan dikenakan zakat dengan menggunakan kaedah pengiraan atau formula yang telah ditetapkan sebagai panduan. ${ }^{58}$ Sebagai contoh di Melaka ${ }^{59}$ penetapan kadar perhiasan emas yang perlu dikeluarkan zakat adalah 200gram. Manakala Wilayah Persekutuan ${ }^{60}$ dengan kadar 150gram. Sedangkan Pahang, 500gram. ${ }^{61}$ Kadar ini berbeza dengan kadar yang telah

\footnotetext{
54 Al-Qaraḍāwī, Fiqh al-Zakāt, 321.

55 'Al̄̄ Jum'ah, al-Kalim al-Ṭayyib Fatāwā 'Așriyyah (al-Qāhirah: Dār al-Salām, 2007), 2 : 110.

56 Mușțafā al-Zarqā, Fatāwā (Damshiq: Dār al-Qalam, 2004), 143.

57 Sa'ad 'Abd Allāh al-Bārik, Fatāwā 'Ulamā' al-Balad al-Harām (Riyāḍ: al-Mamlakah al-'Arabiyyah al-Sa'ūdiyyah, 1999), 243.

58 Lembaga Zakat Selangor, http://www.e-zakat.com.my/zakat-harta/ zakat-emas-perak/, di akses pada 22 Februari 2013.

59 PusatZakat Melaka, http://www.izakat.com/index.php?option=com content\&view=article\&id=7\&Itemid=12\&lang=en, di akses pada 22 Februari 2013.

60 Pusat Pungutan Zakat (PPZ MAWIP), http://www.zakat.com.my/ zakat-emas.html, di akses pada22 Februari 2013.

61 Pusat Kutipan Zakat Pahang, http://www.zakatpahang.my/v2/ EmasPerakDalil.aspx, di akses pada 22 Februari 2013.
} 
ditetapkan bagi negeri Selangor. Hal ini kerana uruf di kawasan tersebut yang berbeza.

Bagi mengabsahkan uruf yang dijadikan sandaran hukum, ia perlu diasaskan kepada kajian semasa dengan menggunakan metod yang jelas bagi memahami kedudukan sebenar pelaksanaan uruf berkenaan. ${ }^{62}$ Pihak LZS akan menjalankan kajian terlebih dahulu secara menyeluruh ke atas masyarakat di Selangor bagi mengetahui gaya pemakaian emas perhiasan oleh masyarakat di negeri ini. Berdasarkan kepada hasil kajian tersebut akan dianalisis bagi penentuan kadar uruf emas perhiasan yang dipakai yang akan dikenakan zakat.

Pengambilkiraan uruf semasa masyarakat sebelum diputuskan kadar yang perlu dizakatkan adalah penting. Hal ini kerana, apabila diteliti dari sudut maslahah pula, penentuan kadar ini adalah wajar. Dikhuatiri akan berlaku sebagai contoh penetapan kadar uruf emas perhiasaan yang terlalu tinggi atau rendah akan menindas golongan yang memiliki emas perhiasaan yang jelas pemilikan kadar emas antara individu adalah berbeza. Justeru, pengaplikasian konsep maslahah dilihat bagi tujuan menjaga harta umat Islam (hifẓ al-māl).

Jadi, penulis melihat kewajaran fatwa yang telah diputuskan di atas. Kajian secara menyeluruh dalam penentuan uruf ini amat penting. Ini kerana penentuan ini secara tidak langsung melibatkan penentuan hukum Islam yang bersifat semasa. Justeru, kajian demi kajian perlu dilaksanakan demi memantapkan pelaksanaan hukum fiqh di Selangor khususnya dan umumnya di Malaysia.

\section{KESIMPULAN}

Daripada hasil analisis yang telah dibuat, fatwa-fatwa mengenai zakat adalah antara yang menjadi kekerapan pengeluarannya di Selangor. Hal ini berlaku adalah disebabkan isu yang menyentuh perkara zakat mengalami proses perkembangan selari dengan

62 Abdullah@Alwi Hassan, "Penyelidikan Sebagai Asas Kemantapan Pengajian Syariah", dalam Mahmood Zuhdi Ab Majid, Dinamisme Pengajian Syariah (Kuala Lumpur: Akademi Pengajian Islam, Universiti Malaya, 2001), 13. 
perkembangan semasa yang berlaku dalam masyarakat. Justeru, fatwa atas sifatnya sebagai respon kepada realiti semasa yang berlaku turut mengambilkira perkembangan yang berlaku. Berdasarkan kajian yang dijalankan, kebanyakan fatwa yang dikeluarkan sepanjang tempoh sepuluh tahun ini dilihat mampu menangani realiti dan perkembangan semasa yang wujud. Namun begitu, kajian turut menemui fakta bahawa masih terdapat fatwa yang belum membuat penelitian rapi terhadap beberapa perkembangan semasa yang berlaku sebelum keputusan fatwa diambil. Keadaan ini berlaku dalam fatwa pengiraan harga bagi zakat padi. Daripada perbincangan di atas rumusan dapat disimpulkan bahawa pengambilkiraan perkembangan semasa dalam penentuan fatwa menjadikan fatwa suatu yang berdaya saing dalam memenuhi keperluan semasa dan masyarakat setempat.

\section{BIBLIOGRAFI}

'Alī Jum'ah. al-Kalim al-Ṭayyib Fatāwā 'Așriyyah. al-Qāhirah: Dār al-Salām, 2007.

'Abd al-Raḥman Ibn Muḥammad al-Dakhīl. al-Fatwā Ahammiyyatuhā, Dawābițhā, Āthāruhā. Baḥth Muqaddam li Nayl Jā'izah Nāyif Ibn Abd al-'Azīz 'Alī Su'ūd al'Ālamiyyah li Sunnah al-Nabawiyyah wa al-Dirāsāt alIslāmiyyah al-Mu'āṣarah, 2007.

Abdul Karim Ali dan Siti Kursiah Mansor, et al. "Faktor Perubahan Pendapat Imam Al-Shafi'i Dari Qawl Qadim Kepada Qawl Jadid”. Jurnal Syariah 16. no. 2. Kuala Lumpur: Akademi Pengajian Islam, Universiti Malaya (2008): 308.

Abdullah@Alwi Hassan. "Penyelidikan Sebagai Asas Kemantapan Pengajian Syariah". Dalam Mahmood Zuhdi Ab Majid. Dinamisme Pengajian Syariah. Kuala Lumpur: Akademi Pengajian Islam, Universiti Malaya, 2001.

Aḥmad Bū'ūd. Fiqh al-Wāqi ‘ Ușūl wa Dawābiṭ. al-Qāhirah: Dār al-Salām, 2006.

Al-Baghawī. al-Tahdhīb fì Fiqh al-Imām al-Shāfi 'ì. Lubnan: Dār al-Kutub al-'Ilmiyyah, 1997. 
Al-Bārik, Sa'ad 'Abd Allāh. Fatāwā 'Ulamā' al-Balad al-Harām. Riyāḍ:: al-Mamlakah al-'Arabiyyah al-Sa’ūdiyyah, 1999.

Al-Bukhārī, Muḥammad Ibn Ismā'il. Șaḥ̄h al-Bukhārī. c. 2. Riyāḍ: Maktabah al-Rushd, 2006.

Al-Jawziyyah, Ibn al-Qayyim. I'lām al-Muwaqqi 'in 'an Rabb al'Ālamìn. al-Qāhirah: Dār al-Ḥadīth, 2004.

Al-Kāsānī 'Alā' al-Dīn Abī Bakr Ibn Mas'ūd al-Hanafî. Badā' 'i ' al-Ṣanā 'i' fì Tartīb al-Sharā' 'i' (tahquīq: 'Alī Muhammad Mu'awwad). Bayrūt: Dār al-Kutub al-Ilmiyyah, 2003.

Al-Khin, Muștafā et al. al-Fiqh al-Manhajī. Damshiq: Dār alQalam, 2000.

Al-Mārdawī, 'Alā' al-Dīn Abī al-Husayn 'Alī Ibn Sulaymān. alInșāf. Bayrūt: Dār Iḥyā’ al-Turāth al-'Arabī, 1998.

Al-Nawawī, Muhyy al-Dīn. Minhāj al-Tạlibìn. Bayrūt: Dāā alBashā'ir al-Islāmiyyah, 2000.

Al-Qaddurī, Aḥmad Muḥammad. Mawsū'ah al-Qawā'id alFiqhiyyah al-Muqāranah (al-Tajrìd). al-Qāhirah: Dār alSalām, 2004.

Al-Qaraḍāwī, Yūsuf. Fiqh al-Zakāt. al-Qāhirah: Maktabah Wahbah, 2006.

Al-Qaraḍāwī, Yūsuf. Taysīr al-Fiqh li al-Muslim al-Mu'āṣir fì Daw'al-Qurān wa al-Sunnah 1. al-Qāhirah: Maktabah Wahbah, 1999.

Al-Shāfi‘̄i, Ibn Idrīs. al-Umm. Bayrūt: Dār al-Kutub al-'Ilmiyyah, 1993.

Al-Shīrāzī, Ab̄̄ Isḥāq. al-Muhadhdhab. Bayrūt: Dār al-Kutub al'Ilmiyyah, 1995.

Al-Suyūṭī, Jamāl al-Dīn. al-Ashbāh wa al-Naz̄ā'ir fì Qawā'id wa Furū' Fiqh al-Shāfi 'iyyah. Mișr: Mușțafā al-Bābā al-Ḥalb̄̄ wa Awlāduhu, 1938. 
Al-Zarqāa, Muḥammad. Sharh al-Qawā 'id al-Fiqhiyyah. Damshiq: Dār al-Qalam, 1998.

Al-Zarqāā, Mușțafā. Fatāwā. Damshiq: Dār al-Qalam, 2004.

Anuar Zaini. "Kemajuan Sains dan Teknologi Kesannya Terhadap Perkembangan Hukum Islam Malaysia Masa kini." Dalam Raihanah Azahari dan Abdul Karim Ali. Hukum Islam Semasa. Kuala Lumpur: Akademi Pengajian Islam, Universiti Malaya, 2001.

e-fatwa, Portal Rasmi Fatwa Malaysia. http://www.e-fatwa.gov. my/fatwa-negeri/fatwa-tentang-kaedah-pembayaran-zakatkwsp, di akses pada 21 Februari 2013.

Ibn Qudāmah. al-Mughnī. Riyāḍ: Dār 'Ālim al-Kutub, 2005.

Ismail Mat. "Pengajian Syariah: Hubungannya dengan Adat Arab dan Keadaan di Malaysia". Dalam Mahmood Zuhdi Ab Majid. Dinamisme Pengajian Syariah. Kuala Lumpur: Akademi Pengajian Islam, Universiti Malaya, 2001.

Kertas Cadangan Penetapan Kadar Zakat Untuk Zakat Padi. Pusat Zakat Selangor (MAIS), 2001.

Kertas Kerja Bil. 6/5/06. BayaranZakatKWSP Sejurus Pengeluaran Satu Altenatif. Jabatan Mufti Negeri Selangor.

Kertas Kerja Cadangan Pembayaran Zakat Fitrah Melalui Pembayaran Elektronik. Lembaga Zakat Selangor, 2011.

Kertas Mesyuarat1/1/2000, Kertas Cadangan Menetukan Satu Kaedah Tetap Bagi Zakat KWSP, Pusat Zakat Selangor (MAIS).

Kertas Mesyuarat 1/1/2001. Pembayaran Zakat Melalui Perkhidmatan Maybank 2U (Internet). Pusat Zakat Selangor.

Lembaga Zakat Selangor. http://www.e-zakat.com.my/fatwanegeri-selangor/, di akses pada 22 Februari 2013. 
Mahmood Zuhdi Ab Majid. Pengurusan Zakat. Kuala Lumpur: Dewan Bahasa dan Pustaka, 2003.

Mālik Ibn Anas. Muwațtầ' al-Imām Mālik. (Tahqīq: Taqi al-Dīn al-Nadwī). Damshiq: Dār al-Qalam, 2005.

Mesyuarat Jawatankuasa Fatwa Negeri Selangor Kali Ke 1/2011. Kertas Kerja Bil. 3/1/2011. Jabatan Mufti Negeri Selangor.

Mujaini Tarimin. Zakat Pertanian Sistem dan Pelaksanaannya. Selangor: Dewan Bahasa dan Pustaka, 1990.

Noor Naemah Abdul Rahman dan Muhammad al-Ghanim. "alMarāḥil al-Latī Tamurru bihā al-Fatwā". Jurnal Al-Risalah. Vol VIII. Edisi 15. Nomor 1. Jambi: IAIN Sultan Thaha Saifuddin Jambi (2008): 107-115.

Noor Naemah Abdul Rahman. "Amalan Fatwa di Malaysia". Jurnal Fiqh 4 (Akademi Pengajian Islam, 2007): 89. Diakses pada 16 April 2013. URL: http://e-journal.um.edu. my/filebank/published_article/3998/Amalan_Fatwa_di_ Malaysia.pdf.

Nurhelmi Bin Ikhsan. Pegawai Perhubungan Awam Jabatan Mufti Negeri Selangor. Temubual pada 02 Mac 2012.

Padiberas Nasional Berhad. (BERNAS). http:// www.bernas.com.my/index.php?option $=$ com content\&view=article $\&$ id $=68$ :rice-types-inmalaysia\&catid=47:ricepedia, 20 April 2012.

Patmawati Hj Ibrahim. "Pembangunan Ekonomi Melalui Agihan Zakat: Tinjauan Empirikal". Jurnal Syariah 16. Kuala Lumpur: Akademi Pengajian Islam, Universiti Malaya (2008): 225.

Pusat Kutipan Zakat Pahang. http://www.zakatpahang.my/v2/ EmasPerakDalil.aspx, di akses pada 22 Februari 2013.

Pusat Pungutan Zakat (PPZ MAWIP). http://www.zakat.com.my/ zakat-emas.html, di akses pada 22 Februari 2013. 
Pusat Zakat Melaka. http://www.izakat.com/index. php?option $=$ com_content\&view $=$ article $\& i d=7 \&$ Itemid $=12$ \&lang=en, di akses pada 22 Februari 2013.

Zulkiple Abd Ghani. "Teknologi Maklumat: Hubungannya Dengan Perkembangan Hukum Islam Semasa", dalam Raihanah Azahari dan Abdul Karim Ali, Hukum Islam Semasa. Kuala Lumpur: Akademi Pengajian Islam, 2001.

Zaydān, 'Abd al-Karīm. al-Madkhal li Dirāsah al-Sharī'ah alIslāmiyyah. Bayrūt: Mu'assasah al-Risālah Nāshirūn, 2009. 
Jurnal Fiqh, No. 10 (2013) 91-118 